\title{
Application of practice-oriented technologies in teaching undergraduates in creative areas of training
}

\author{
Vladimir Mikryukov ${ }^{1 *}$,Elena Orlova $^{1}$, Anastasia Mazhura $^{2}$, Ekaterina Mladkovskaya ${ }^{2}$, and \\ Alexander Milyanenko ${ }^{2,3}$ \\ ${ }^{1}$ Financial University under the Government of the Russian Federation, Department of Sociology, \\ Moscow, Russia \\ ${ }^{2}$ Moscow Pedagogical State University, Departament of Journalism and Media Communications, \\ Moscow, Russia \\ ${ }^{3}$ Military University of the Russian Ministry of Defence, Moscow, Russia
}

\begin{abstract}
The article analyzes the experience in the application of practice-oriented technologies in teaching students in creative areas of "Journalism", and "Advertising and Public Relations" at higher education institutions in Moscow and the Moscow Region. The purpose of the conducted research is to identify the most effective practice-oriented technologies in the preparation of bachelors in the field of journalism, advertising, and public relations to the benefit of a modern metropolis. The authors give the classification of technologies and their effect on the result of students' education and reveal how a particular technology is used in the training of university students. The article considers specific examples of technologies, their relevance, and impact on the level of professional training of university graduates, as well as on improving their competitiveness. The article also presents the analysis results of the students' and graduates' opinions (using the method of a free interview of 97 respondents without sample calculation) that confirms the main hypothesis that the structure of knowledge and skills of future specialists is being changed, as well as the level of preparedness to work in the metropolis and large cities. The present article summarizes the authors' long-term experience in applying practice-oriented technologies in teaching students at many universities where the authors worked. Keywords: practice-oriented technologies, metropolis, journalism, advertising, and public relations.
\end{abstract}

\section{Introduction}

The problem of high-quality training of university graduates in the contemporary metropolis has become very acute. Business, government, and city agencies expect that young people, who have completed their university degrees will quickly socialize and start

\footnotetext{
* Corresponding author: mikryukov.v.o@gmail.com
} 
performing their official duties. But in fact, one can often come up against a situation where students' knowledge in creative areas, such as journalism, advertising, and public relations quickly becomes outdated, and students often get more theoretical knowledge than practical skills. This affects the fact that they cannot quickly find a job in a metropolis in the field of training that they have devoted four to five years of their life to.

According to the authors, the above-mentioned and other problems can be solved using, among other things, practice-oriented learning technologies. This article describes the authorial developments in this area, as well as the results of their application.

\subsection{Authorial analysis of a problem}

Researchers in Russia and other countries are actively studying the development and implementation of practice-oriented technologies in students' training. Here one should mention Russian scientists, such as Ye. M. Avlasovich [1], A.G. Bermus, O.Kh. Miroshnikova [2], O.S. Vasilyeva, A.I. Markeyev [3], D.M. Tsukerblat [4], S.A. Melkov, V.O. Mikryukov, A.Yu. Lyabakh [5], M.M. Olesova [6], V.Z. Techiyeva [7], A.V. Fefelkina [8], and others, as well as foreign specialists, namely, B. Bowyer, J. Kahne [9], C.B. Cox, A. House, A. Lopez, G.J. Pool [10], M. Flavin [11], E. Fleaca, R.D. Stanciu [12], F. Habibi, M.A. Mohamad [13], N. Iivari, S. Sharma, L. Ventä-Olkkonen [14], R. Litterscheidt, D.J. Streich [15], H. Santos, J., Batista, R.P. Marques [16], M.J. Sousa, M. Carmo, A.C. Gonçalves, R. Cruz, J.M. Martins [17].

\section{Methods}

This article uses general scientific research methods (analysis of specialized literature, synthesis of practical knowledge of the authors in the field of teaching various disciplines in several Russian universities, observation, etc.), as well as the method of free interview, whose results are discussed below.

\section{Results}

First, the authors define the practice-oriented technologies which are understood as a set of training and education technologies which are focused on solving professional and/or everyday tasks that are faced by specialists working in advertising and public relations. The main purpose of using such technologies is to immerse students in solving professional problems in the field of training and major, which are taken from the real practice of advertising and PR agencies, information departments of state and local government bodies, as well as business.

Below are examples of the application of some practice-oriented technologies in the training of bachelors majored in journalism, advertising, and public relations to the benefit of the metropolis, which are used in teaching practice by the authors of the present article.

\subsection{Solving cases}

A case is a situational problem that requires the student to know and understand the essence of the processes that are presented in the case, as well as to develop several proposals for its solution. Cases are taken from the operating experience of agencies and other establishments. Solving the case is giving answers to questions that are essentially concerned with the formulation of specific proposals for improving certain conditions set out in the case condition. 
The training, such as the case, has been used for a long time in the Financial University under the Government of the Russian Federation (hereinafter - the Financial University), Moscow Pedagogical State University (hereinafter -MPGU), and the Civil Defence Academy of Emergency Control Ministry (EMERCOM) of Russia (hereinafter - CDA), as well as in other universities. Thus, students of the Financial University solve cases on the subject of "Public opinion survey", "Brand management", etc. at each practical lesson. They are immersed in the situations that specialists face in practice, thus they begin to understand the difficulties of the profession studying at the university, and learn to overcome them. In the CDA, students, and cadets solve cases that are related to informing the population about emergency situations, as well as responding to the negative attitude towards the EMERCOM of Russia. Students specializing in the areas of "Advertising and Public Relations" and "Journalism" of MPGU actively work with cases in the framework of creative studios.

\subsection{Solving practical problems in advertising and PR}

Often it is extremely difficult and long to get a job after graduation without having practical experience. Therefore, it is necessary to bring practice-oriented technologies to the fore. For example, students of the Financial University solve problems on calculating advertising performance indicators, conduct a lot of research on rebranding using examples of specific brands, rather than in theory, calculate the financial and other costs of digital marketing, and learn to set goals to improve conversion rate. Teachers (the authors of this article) do not take data for such tasks accidentally but get them from real agencies with which they have close ties, as well as from their experience in the field of advertising and public relations, and journalism.

\subsection{Tasks to develop the creative potential of the student's personality}

These tasks include assignments that are given during a job interview, as well as when working in front of a camera during taking an interview as a press service employee, creating a visual image for advertising, brand identity, etc. It is worth noting that such tasks are not only useful but also very popular with students. Students are happy to perform them and are always involved in the process during class sessions.

\subsection{Business games}

These can be a variety of situations where students play the role of an advertising agency employee, press secretary, journalist, etc. The main task is to immerse students in the profession as deeply as possible so that they feel in it and start thinking and offering solutions to a specific problem. For example, business games are held with students of the Financial University, where they perform the roles of different specialists in the advertising agency's departments to solve a real problem (for example, a drop in the quality of targeted advertising traffic). As a result, they look for a solution, offer it, and defend their point of view. Thus, they get used to some of the social roles that they will play if they work in such an agency after graduation. Intriguing is the experience of the MPGU, where journalist students have been covering the activities of the admissions committee within the students' press center for six years. Students learn to work in real-time mode, observing the requirements of the developed sections, genres, and formats of material, communicate with representatives of different faculties and institutes, develop communication skills, and go through the entire cycle of creating an information product from idea to publication. 


\subsection{Organizing training and field trips to advertising and PR-agencies and other organizations}

It would seem that there is nothing new here. But this technology is used not in every university. Positive experience is shown by the CDA, where internships are organized annually starting from the first year. This activity is given maximum attention. Students are required to get the maximum experience in developing press releases, shooting stories, multimedia support for the activities of the EMERCOM of Russia, etc.

\subsection{Working with technical devices and special programs, and products from the arsenal of practitioners}

This means working with photo and video cameras, sound recording equipment, etc. Besides, students learn to work with services, such as Statistical Package for the Social Sciences (SPSS), products of companies, such as Medialogia, YouScan, Brand Analytics, etc., which are used for media monitoring.

\subsection{Organizing and conducting master classes for students and by students}

These training events involve practitioners from organizations in various industries that allow students to decide on further priorities for development and specialization in the profession. The second format of masterclasses is the work of third-year students with firstyear students. The students are happy to share acquired experience and skills with each other in photography, volunteering, job search, $\mathrm{SEO}^{\dagger}$-promotion of websites, etc.

\subsection{Organizing students' volunteer activities at various events at the urban and federal level}

Volunteer participation of students in the framework of the creative studio in preparing and organizing large-scale events at the urban and federal levels gives maximum immersion in the profession within a short time. An additional effect of these activities is the opportunity to listen to speakers in various areas of the advertising and PR industry, as well as to learn the latest market trends.

At that, it should be emphasized that short-term immersion in the profession does not substitute industrial practice.

\subsection{Organizing independent project activities of students}

Students' project activities are actively implemented within the framework of the creative studios of MPGU. This form of training is harmoniously integrated into the educational process and has actually become a part of it. At the Financial University, students are involved in projects and research in several disciplines. This approach allows students to try out the functions of a creator, organizer, researcher, and apply their analytical skills. The most popular among students are socially significant project topics, many of them are focused on the development of the urban community. It is worth noting that the final qualification work can also be a description of the implemented project, depending on the training area in marketing, advertising, PR, or journalism.

\footnotetext{
$\dagger$ Search engine optimization
} 
While understanding the complexity of the scientific problem of using practice-oriented technologies, it was decided to survey third-fourth-year students, as well as graduates of the training areas "Advertising and Public Relations" and "Journalism" of universities in Moscow and the Moscow Region in the form of a free interview on the main problems they faced or had encountered in employment.

A total of 137 students and 67 university graduates were interviewed. The results obtained and conclusions are summarized below.

\section{Discussion}

The main difficulties that students faced when applying practice-oriented technologies were identified as follows:

- the complexity of the wording of some tasks;

- because of the small amount of time allocated to the lesson, it was impossible to quickly understand the essence of the problem and work out proposals for its solution as thoroughly as possible;

- difficulties related to mathematical, statistical, and other calculations;

- lack of real work experience in the field of training/specialty;

- poorly developed communication skills to rapidly engage in teamwork;

- the difficulty of combining volunteer activities with training, etc.

Also, university graduates, who already worked in agencies, media offices, press services, and other agencies paid attention to the maximum possible involvement of students in the work in the field of training/specialty. In their opinion, the faster students felt themselves in a certain role in an agency or other establishment, the more they would be willing to learn and delve into the subtleties of the profession (more than $87 \%$ of respondents believed this). Therefore, the use of practice-oriented technologies is no longer a trend, but an urgent necessity.

\section{Conclusion}

The experience of using practice-oriented technologies by the authors of the present article, as well as the results of a study of the students' and graduates' opinions, clearly demonstrated not only the timeliness and relevance of the implementation of this method of training but also its high efficiency. Practice-oriented technologies significantly increase the competitiveness of graduates of creative areas of training, such as "Advertising and Public Relations" and "Journalism" in the labor market of metropolises, as well as increase the level of employment. Besides, due to the effective mastering of professional skills in parallel with acquiring theoretical knowledge, students can find a job before graduation, thereby guaranteeing further rapid professional advancement that is extremely important in large cities.

\section{References}

1. Y.M. Avlasovich, Research and Scientific Electronic Journal of Omsk State Agrarian University, Special issue 3, 1-5 (2017). Accessed on: December 20, 2020. [Online]. Available: http://e-journal.omgau.ru/index.php/spetsvypusk-3/36-spets03/734-00319

2. A.G. Bermus, O.Kh. Miroshnikova, Nauchnyy dialog, 10(46), 8-23 (2015)

3. O.S. Vasilyeva, Terra economicus, 11(2.3), 115-119 (2013)

4. A.I. Markeev, D.M. Tsukerblat, Siberian pedagogical journal, 3, 83-92 (2019). 
http://dx.doi.org/10.15293/1813-4718.1903.08

5. S.A. Melkov, V.O. Mikryukov, A.Yu. Lyabakh, Dolzhen Li Vypusknik Rossiyskogo Vuza Vladet' Analiticheskimi Navykami? (Na Primere Napravleniya "Gosudarstvennoye I Munitsipal'noye Upravleniye”) [Should a graduate of a Russian university have analytical skills? (on the example of the direction "State and municipal management"), in Proceedings of the Conference Prikladnyye Nauchnyye Issledovaniya I Eksperimental'nyye Razrabotki, Osnovannyye Na Rezul'tatakh Fundamental'nykh I Poiskovykh Issledovaniy, 6-7 December 2016, Moscow, Russia (2017)

6. M.M. Olesova, Philology. Theory and practice, 7(73-2), 201-204 (2017). Accessed on: December 20, 2020. [Online]. Available: https://www.gramota.net/materials/2/2017/72/58.html

7. V.Z. Techiyeva, Siberian pedagogical journal, 1, 82-90 (2019). https://doi.org/10.15293/1813-4718.1901.10

8. A.V. Fefelkina, Mir obrazovaniya - obrazovaniye v mire, 2(66), 198-203 (2017). Accessed on: December 20, 2020. [Online]. Available: http://www.mpsu.ru/sites/default/files/files/pub/mir_obrazovaniya_02_2017.pdf

9. B. Bowyer, J. Kahne, Journal of Applied Developmental Psychology, 69, 101162 (2020). https://doi.org/10.1016/j.appdev.2020.101162

10. C.B. Cox, A. House, A. Lopez, G.J. Pool, Industrial and Organizational Psychology, 10(4), 696-701 (2017). https://doi.org/10.1017/iop.2017.78

11. M. Flavin, Oxford Review of Economic Policy, 32(4), 632-645 (2016). https://doi.org/10.1093/oxrep/grw028

12. E. Fleaca, R.D. Stanciu, Procedia Manufacturing, 32, 1051-1057 (2019). https://doi.org/10.1016/j.promfg.2019.02.320

13. F. Habibi, M.A. Mohamad, Technology in Society, 63, 101370 (2020). https://doi.org/10.1016/j.techsoc.2020.101370

14. N. Iivari, S. Sharma, L. Ventä-Olkkonen, International Journal of Information Management, 55, 102183 (2020). https://doi.org/10.1016/j.ijinfomgt.2020.102183

15. R. Litterscheidt, D.J. Streich, Journal of Behavioral and Experimental Economics, 87, 101573 (2020). https://doi.org/10.1016/j.socec.2020.101573

16. H. Santos, J. Batista, R.P. Marques, Procedia Computer Science, 164, 123-130 (2019). https://doi.org/10.1016/j.procs.2019.12.163

17. M.J. Sousa, M. Carmo, A.C. Gonçalves, R. Cruz, J.M. Martins, Journal of Business Research, 94, 227-240 (2019). https://doi.org/10.1016/j.jbusres.2018.02.005 